\title{
EDUCAÇÃO EM SAÚDE BUCAL PARA CRIANÇAS COM SÍNDROME DE DOWN- PROTOCOLO DE HIGIENE BUCAL
}

Anderson COSTA, Rafaela Elvira ROZZA, Fabian Calixto FRAIZ

A odontologia deve utilizar ações educativas bem direcionadas, as quais permitirão à criança com Síndrome de Down manter sua saúde bucal. Este trabalho se propõe a elaborar um protocolo de orientações da higiene bucal que permita à equipe de saúde bucal a adoção de posturas e medidas adequadas para crianças com Síndrome de Down e seus familiares e responsáveis. A Síndrome de Down é uma condição genética decorrente da presença de material genético extra no cromossomo 21. Sua incidência é de uma para cada 700 crianças (TOLEDO, 1986). Muitas das características bio-psicosociais apresentam conseqüências diretas com a saúde bucal e com a qualidade de vida destas pessoas e seu núcleo familiar. Uma destas conseqüências é a maior predisposição à doença periodontal, a qual ocorre devido a um sistema imunológico deficiente, menor desenvolvimento do sistema mastigatório, dificuldade na higienização bucal e apinhamento dentário (HENNEQUIN, 1999). Ações como a exploração do ambiente bucal, estimulação da musculatura facial, a qual normalmente é hipotônica e o desenvolvimento da neuromotricidade da criança, condicionam a realizar uma correta escovação dentária (HENNEQUIM,1999). Esse protocolo visa desmistificar a atenção odontológica para estes indivíduos e promove sua inclusão no esforço da sociedade buscando melhores condições de saúde. 